\title{
Caught in the Web: The Impact of Library Instruction on Business Students' Perceptions and Use of Print and Online Resources
}

\author{
Shawn V. Lombardo and Cynthia E. Miree
}

\begin{abstract}
Many business students rely heavily on the Web for research, in part because of their unfamiliarity with the breadth of their library's business resources (online and in print). This study sought to determine whether library instruction could impact undergraduate business students' attitudes and use of three information formats: print materials, library databases, and Web resources. Over the course of a semester, pre-/ postinstruction questionnaires were collected from ninety students enrolled in a business capstone course. Results indicate that after library instruction, students held more favorable attitudes toward print resources and used them in their research more than they had initially expected.
\end{abstract}

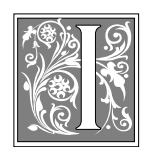

n today's fast-paced world, the desire for expediency has prompted undergraduate students to place a premium on information that can be found quickly and easily. To this end, many students limit their research to electronic resources, choosing format over substance and convenience over accuracy. In particular, reliance on the World Wide Web as a primary-and often sole-research tool has impacted the quality and rigor of student projects and reduced students' familiarity with more traditional print resources and bibliographic databases in their university's library collection. Given this trend, more than ever it is imperative that librarians, in collaboration with academic faculty, take a central role in introducing students to the full array of research tools at their disposal. Past research has demonstrated that library instruction can influence students' general attitudes toward the library and its resources; more work must be done, however, to measure the impact of library instruction on students' perceptions of specific information formats. Equally important, librarians must fully examine how library instruction impacts students' use of these resources.

The current study was designed to measure business students' initial perceptions and use of three information formats: the Web, online bibliographic and full-text databases, and print reference resources. Further, the authors wanted to explore the impact of library instruction on students' attitudes about and use of

Shawn V. Lombardo is an Assistant Professor and Business Librarian in the Kresge Library at Oakland University; e-mail: lombardo@oakland.edu. Cynthia E. Miree is an Assistant Professor of Management at Oakland University; e-mail: miree@oakland.edu. 
these research tools. The study was guided by the following research questions:

- Can library instruction impact undergraduate business students' perceptions of the Web, online databases, and print resources?

- Can library instruction affect students' use of these resources in completing a business-related research project?

The development of more comprehensive, relevant, and easily searchable subject directories and search engines (e.g., Yahoo, Google) and the ubiquity of the Web have resulted in a generation of students who now perceive the Internet as the most familiar, convenient, and expedient source of information.

\section{Literature Review}

Studies on research behavior have demonstrated that students are drawn to information sources that allow them to complete their research, as Barbara Valentine wrote, in the "easiest, least painful way," choosing research tools based on ease of use and favoring convenience of access over quality of information. ${ }^{1}$ Valentine's research revealed that students tend to avoid resources they are unfamiliar with or believe are difficult to use, returning to tools they have used successfully in the past. ${ }^{2}$ As a result, many students turn to electronic resources for their research needs. Peggy Seiden, Kris Szymborski, and Barbara Norelli found that students favor electronic resources primarily for their convenience and efficiency and indicated a strong preference for full-text access to information. ${ }^{3}$ In a separate study conducted by Debbie Malone and Carol Videon, students most frequently cited ease of use as their reason for selecting electronic resources over print materials. ${ }^{4}$

Until recently, students were enamored of subscription-based library databases for their convenience and ease of use as compared with the library's paper indexes and other print materials. In a 1996 study of incoming students at St. Olaf College, Bryn
Geffert and Beth Christensen found that more students had used an electronic periodical index than had used the Web. ${ }^{5}$ And a 1998 study by Brad MacDonald and Robert Dunkelberger revealed that students first turned to Searchbank-more frequently than even the Web-when beginning their research. Unfortunately, these students also tended to limit their search in the database to just those articles that were available full-text. ${ }^{6}$

The development of more comprehensive, relevant, and easily searchable subject directories and search engines (e.g., Yahoo, Google) and the ubiquity of the Web have resulted in a generation of students who now perceive the Internet as the most familiar, convenient, and expedient source of information. In a study of freshman English students at the University of Louisiana, Bradley P. Tolppanen found that one-half of those surveyed turned to the Web first for information. ${ }^{7}$ And WenHua Ren's 1999 study at Rutgers University revealed that 45 percent of the undergraduates surveyed used the Internet daily. In contrast, one-half of the students used the library's databases only occasionally and 40 percent had never used them at all. ${ }^{8}$ Citation analyses of student bibliographies further demonstrate students' dependence on the Web. In a longitudinal study of the bibliographies of undergraduate student term papers from 1996 to 1999, Philip M. Davis and Suzanne A. Cohen observed that, although the total number of citations remained unchanged over time, there was a significant decline in the number of books cited, with a concurrent increase in the number of Web site citations. ${ }^{9}$ An update to this study revealed that, compared with previous years, a majority of student bibliographies in 2000 included more citations to Web sites than to other information formats. ${ }^{10}$

This trend toward exclusive use of the Web for research has raised concerns among academic and library faculty. Susan Davis Herring found that although faculty accept the Web as a valid research tool, they nevertheless question their students' ability to think critically about the 
information they find-and with good reason. ${ }^{11}$ Deborah J. Grimes and Carl H. Boening observed that students often fail to evaluate Web-based information for authorship, currency, and bias. ${ }^{12}$ And Tolppanen reported that a discouraging 92.5 percent of students surveyed believed that the information they find on the Web is accurate. ${ }^{13}$ Other studies have demonstrated clearly that students do not comprehend this new digital environment. They do not understand the content of the Web nor can they distinguish between a Web site and a bibliographic database that is accessed via the Internet. ${ }^{14,15}$ Yet, many students are confident-perhaps overconfident-using the Web, believing that the Internet has made them self-sufficient researchers. ${ }^{16}$ Worse still, Grimes and Boening found that students do not perceive librarians as a resource to turn to for assistance in searching the Web and, as a result, often search on their own, inexpertly and inefficiently. ${ }^{17}$ Finally, Davis and Cohen suggested that students' work has become less rigorous, in part, because they restrict the type and range of scholarship they use in their research activities, neglecting other potentially valuable information sources. ${ }^{18}$

Unfortunately, although the Internet opens the door to a wealth of business-related data, reliance on the Web also can result in the neglect of important information housed in traditional print resources and online databases.

Many students avoid print resources at all costs because of their inconvenience and perceived difficulty. The students experience real frustration in accessing print materials and often are unaware of the purpose, scope, and content of an academic library's reference collection. ${ }^{19,20}$ In a study of students enrolled in a freshman-level writing course, Shawn V. Lombardo and Kristine S. Condic found that more than 35 percent of undergraduates ignored citations to articles available in the library in print format in favor of citations to online articles. ${ }^{21}$ Further, onequarter of the library users surveyed at the University of North Carolina indicated that they would never use print resources under any circumstances. ${ }^{22}$ Students want to complete their research with a minimum of time and effort and, for many of them, the library's electronic resources are the only answer. Unfortunately for these students, print resources are replete with valuable information (both current and historical) that often cannot be found on the Web.

With such a strong bias among students toward using the Web as their primary research tool, library instruction should be considered a crucial means of introducing students to print materials and electronic resources besides the Web. Numerous researchers have used a pre-/ posttest methodology to demonstrate positive change in students' research skills and knowledge of the library and its resources after library instruction. ${ }^{23}$ Other researchers have used surveys and qualitative methods such as focus groups to measure changes in students' attitudes as outcomes of library instruction. These studies demonstrate that library instruction can positively impact such perceptions as students' confidence in their research skills, self-efficacy in searching electronic resources, and satisfaction with the library. ${ }^{24-26}$ Fewer studies have shown that library instruction can influence students' actual use of research tools. ${ }^{27}$ However, most of these studies do not address student use of print resources-still a valuable format for much business data.

How well do business students fit into the research patterns and attitudes of other students? In a study that used both survey and observation methods to investigate business students' research behaviors and attitudes toward information resources, Joseph D. Atkinson III and Miguel Figueroa observed that a majority of business students favored electronic resources over print materials, primarily for their convenience, ease of use, and speed. In fact, many of these students assumed that elec- 
tronic resources would provide answers quickly and were surprised when they located information in print resources more easily. When asked to identify information resources with which they were familiar, subjects identified Internet resources about as often as library databases but cited print resources much less frequently. ${ }^{28}$ The study also indicates that business students valued their time, seeking "immediate tradeoffs in their allocation of time versus the amount of relevant information retrieved" and going so far as to end their research when the time they allotted themselves to complete the research was finished, rather than when their information needs were filled. ${ }^{29}$ Similarly, Thomas R. Mirkovich, in a study of the library use patterns of undergraduate business and MBA students, found that library use by business students was very light. These students were unaware of the types of business resources available to them and received little guidance from their faculty. ${ }^{30}$ Atkinson and Figueroa further asserted that business students, by the nature of their academic discipline, are predisposed to these perceptions. ${ }^{31}$ Business students and professionals alike see the value of time ("Time is money") and the importance of keeping current with new technologies to maintain a competitive advantage; thus, it seems likely that they would turn most often to the Web for their information needs.

Unfortunately, although the Internet opens the door to a wealth of business-related data, reliance on the Web also can result in the neglect of important information housed in traditional print resources and online databases. Further, the Web (at least the portion that is available freely) is not necessarily the most efficient place to begin looking for discrete business data and statistics (such as industry ratios), especially for inexperienced searchers. Business information on the Web is often fragmented, making thorough searches for information on a particular company or industry difficult and time-consuming.

To combat business students' perceptions, Atkinson and Figueroa suggested that library instruction for these students should emphasize "cost-effectiveness and time-efficiency when retrieving print resources versus electronic resources. ${ }^{\prime \prime 2}$ But given that business students are predisposed to think favorably about online resources and that a plethora of company and industry data is available on the Web (without respect to the accuracy and objectivity of that information), how successful can a librarian and a management professor be in persuading students to use a full range of business information resources, including print resources and subscription-based databases, to complete a major research assignment? The authors of this study attempted to address this question by exploring whether undergraduate business students at Oakland University shared similar attitudes toward online and print business resources as those demonstrated in the literature and by investigating whether library instruction could affect students' perceptions, biases, and use of information resources in completing a research project.

\section{Methodology \\ Procedures}

The study sample was drawn from three sections of a required business class during the fall of 2001. This class, known as Strategic Management, requires students to study how companies position themselves to compete in various industries. Although the class was mandatory, participation in the study was voluntary and those students who chose to participate were given extra credit. The study was conducted in three phases.

Phase one: On the first day of class, after the instructor described the research project required for the class, the business librarian explained the study and solicited subjects. The students who enrolled in the study then completed a questionnaire designed to capture their knowledge of, attitudes about, and experiences using three information formats: library print resources, library databases and Web resources. ${ }^{33}$ In addition, students were asked to assess their ability to complete the research required for the class 
and to predict which types of resources they expected to rely on most heavily to complete the project.

Phase two: Approximately five weeks into the semester, the business librarian introduced students to business research tools available at or through the library. The librarian began the session with a discussion of the benefits and problems of the three resource types and solicited student opinions about each resource type. In addition, she emphasized the importance of using a variety of resources when conducting research. This discussion was followed by a demonstration of individual resources. Finally, the librarian provided students with an extensive handout that categorized different types of Web, database, and print business resources along with their location in the library or online. For those resources available in both electronic and print formats, both locations were given. After the formal instruction, students completed a brief exercise that required them to answer business-related questions using the resources presented to them during the session.

Phase three: Phase three consisted of two parts. During the last week of class, students returned to the library for a follow-up session wherein the librarian provided instruction on proper citation format for Web, database, and print resources. On the last day of class, participants handed in their research projects and completed a second questionnaire that was designed to capture their knowledge, attitudes, and experiences regarding the different information formats, as well as their perceptions of the research project and their library use during the course of the semester. To maintain confidentiality, all of the instruments used in this study had an identifying number linking them to each other, but not directly to individual students. The resulting data were analyzed using the SPSS statistical package.

\section{Sample}

At the beginning of the semester, 102 subjects enrolled in the study. Subjects were required to attend two library sessions, complete two exercises, and fill out two questionnaires in order to be included in the study. Students who did not complete all three phases of the study were automatically dropped from the sample. By the end of the semester, twelve subjects either withdrew or were eliminated based on their inability to complete the study. The final sample consisted of ninety students.

The average age of the students was 24 years, and the average GPA was 3.10. Table 1 summarizes other relevant demographic information. Because the researchers were interested in prior research behavior, they tried to determine how the students had used the library in the past and where they preferred to conduct their research (table 2). At the beginning of the study, 63 percent of the stu-

\begin{tabular}{c} 
TABLE 1 \\
Sample Demographics \\
\hline \hline
\end{tabular}

\begin{tabular}{lcc} 
Major & Frequency & Percent \\
\hline MIS & 39 & 43.3 \\
Marketing & 15 & 16.7 \\
General management & 11 & 12.2 \\
Human resource & & \\
$\quad$ management & 10 & 11.1 \\
Accounting & 9 & 10.0 \\
Finance & 4 & 4.4 \\
Other & 2 & 2.2
\end{tabular}

\begin{tabular}{lrc} 
Work Status & & Percent \\
\hline Works part-time & 42 & 46.7 \\
Works full-time & 41 & 45.6 \\
Does not work & 7 & 7.8
\end{tabular}

Academic Status Percent

\begin{tabular}{lcc}
\hline Part-time student & 13 & 84.4 \\
Full-time student & 76 & 14.4 \\
Gender & & Percent \\
\hline Female & 54 & 60.0 \\
Male & 36 & 40.0
\end{tabular}

Average Age $24.3(\min .=19 ;$ max. $=48)$

Average GPA $3.1(\min .=2.6$; $\max .=3.8)$ 
TABLE 2

Preinstruction Library Use and Research Preferences

Reason Student Uses the Library Most Often

\begin{tabular}{cr} 
Frequency & Percen \\
\hline 30 & 33.3 \\
27 & 30.0 \\
26 & 28.9 \\
7 & 7.8
\end{tabular}

Number of Visits to the Library in a Semester

\begin{tabular}{lrr}
\hline Student never goes to the library & 8 & 8.9 \\
$1-4$ times per semester & 35 & 38.9 \\
$1-4$ times per month & 27 & 30.0 \\
$1-4$ times per week & 17 & 18.9 \\
About once a day & 3 & 3.3
\end{tabular}

Location Used Most Often for Research

\begin{tabular}{lrr}
\hline Computer at home & 43 & 47.8 \\
Other computer labs at the university (besides the library) & 19 & 21.1 \\
University library & 17 & 18.9 \\
Computer at work & 5 & 5.6 \\
Another university's library & 2 & 2.2 \\
Library at place of employment & 1 & 1.1
\end{tabular}

\section{Preferred Resource at Preferred Location}

\begin{tabular}{lrr}
\hline Web resources & 74 & 82.2 \\
Library databases & 15 & 16.7 \\
Library print resources & 1 & 1.1
\end{tabular}

Type of Resource Typically Used First

\begin{tabular}{lcr}
\hline Web resources & 75 & 83.3 \\
Library databases & 14 & 15.6 \\
Library print resources & 1 & 1.1 \\
& & \\
Type of Resource Used Most Often & 75 & 83.3 \\
\hline Web resources & 14 & 15.6 \\
Library databases & 1 & 1.1 \\
Library print resources & & \\
& 36 & 40.0 \\
Number of Business-related Research Projects in the Past Two Years & 34.4 \\
\hline -3 projects & 31 & 23.3 \\
4-6 projects & 21 &
\end{tabular}

dents use the library primarily as a place to study, use the school's computers, or attend group meetings. Approximately 48 percent of the students historically had visited the library four times or less in a given semester, compared with 52 percent who visited the library once a month or more. Taken together, these numbers suggest that the students who had visited the library most often probably used it for activities other than doing research. More than half the students at the beginning of 
the study also preferred to do their research on a computer (either at work or at home). Finally, students indicated that they used the Web first and more often than library databases or print resources to complete research projects.

\section{Measures}

To measure familiarity with different resource types, students were given a list of ten frequently used print resources, ten library databases, and ten Web sites commonly used for business and economic research (e.g., Standard and Poor's Industry Surveys, ABI/Inform, the Securities and Exchange Commission Web site) and asked to indicate, on a five-point likert scale, the extent to which they had used those resources ( $1=$ I have never heard of this resource; $5=$ I have used the resource to a great extent). Their responses were averaged for each resource type and assigned a "familiarity score" ranging from 1 to 5 for each resource type. Paired t-tests were performed to measure differences in the students' familiarity with the three information formats.

In an effort to understand students' attitudes about, and actual use of, the three types of information resources, the researchers looked at the following attitudinal variables: convenience of using the resource, perceived reliability of informa- tion contained in the resource, perceived ability to find information quickly using the resource, ease of use, frustration using the resource, perceived currency of information contained in the resource, and ability to use only that resource to find all necessary information. Students were asked to express the extent of their agreement with statements about each of the different resource types using a five-point Likert scale ( 1 = strongly disagree; $5=$ strongly agree). Table 3 provides examples of these statements for library databases; the statements on print and Web resources used the same question stem. Because the researchers were interested in determining whether instruction could influence students' attitudes, the same questions were used on the final questionnaire completed at the end of the semester.

\section{Results}

\section{Findings on Students' Attitudes}

The researchers found, not surprisingly, that the students were most familiar with Web resources; interestingly, though, they were more familiar with the library's print resources than its online databases $\left(\right.$ mean $_{\text {web }}=2.67$, mean $_{\text {print }}=2.09$, mean $\left._{\text {databases }}=1.82\right)$. Their level of familiarity with each type of resource varied significantly $\left(\right.$ mean $_{\text {print }}-\mathrm{m}_{\text {databases }}=.23$,

\section{TABLE 3}

Attitudinal Questions (about library databases)

In general, the business-related information found in LIBRARY DATABASES is reliable.

LIBRARY DATABASES are easy to use.

LIBRARY DATABASES are convenient to use.

In general, I think that I can find all the information I need to complete business-related research using only LIBRARY DATABASES.

In general, business-related information can be found quickly using LIBRARY DATABASES.

Current business-related information can be found on LIBRARY DATABASES.

Business-related information for the past five years can be found on LIBRARY DATABASES.

I find using LIBRARY DATABASES to be very frustrating. 


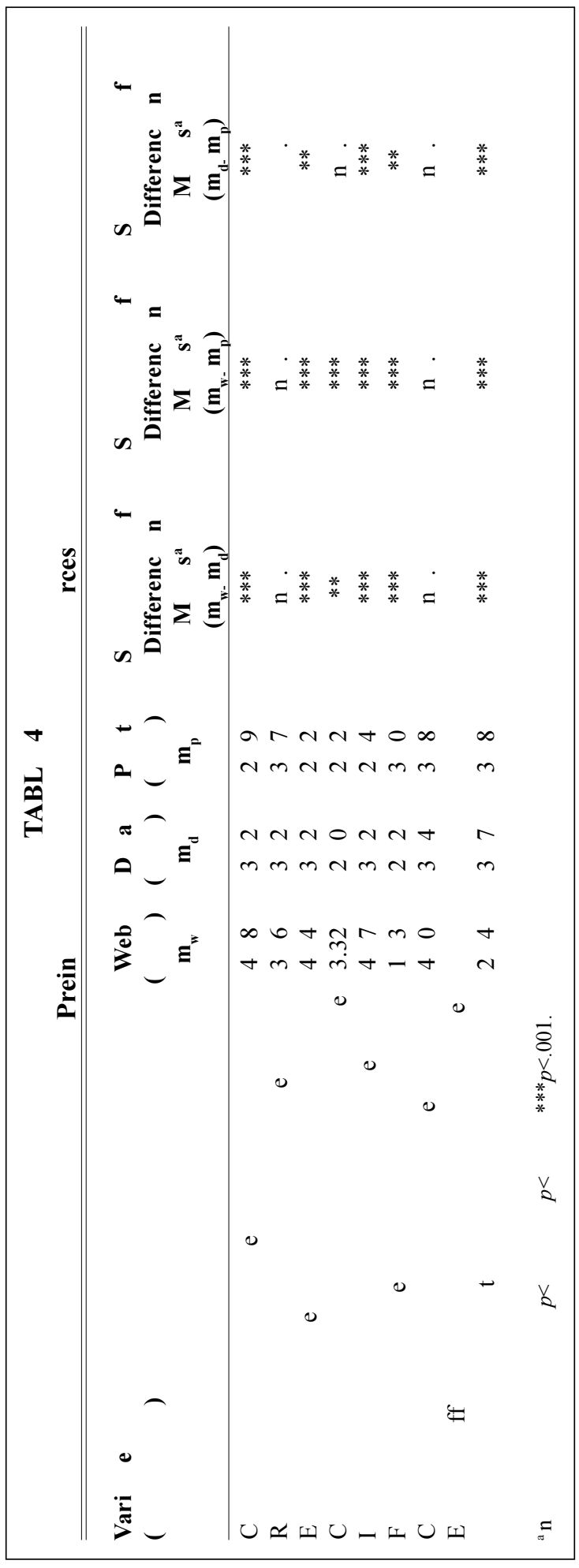

$p<.01$, mean databases - mean $_{\text {web }}=-.85$, $p<.001$, mean print $^{-}$mean $_{\text {web }}=-.57$, $p<.0001)$.

In keeping with Atkinson and Figueroa's assertion that business students are predisposed to think favorably about electronic resources, ${ }^{34}$ an attempt was made to measure subjects' attitudes toward $t$ he three different resource types-Web resources, library databases, and library print materials-prior to instruction. The researchers were interested particularly in those perceptions that could be influenced by instruction. In addition to the list above, the researchers also examined each of the resources in regard to the following two variables: confidence in information obtained from the resource, and perceived difficulty finding information using the resource.

The data were analyzed using paired t-tests; table 4 contains the results of this statistical analysis. Prior to library instruction, students felt that Web resources were much easier to use and more convenient than either print resources or library databases. In addition, they expressed more frustration with print resources than with the other two resources. And although the students believed that the information retrieved from the three resources was equally reliable, they also thought they would have a lot more difficulty finding this information in print resources and databases than on the Web. Also notable is their perception of the comprehensiveness of Web resources: the students believed they were more likely to find all of the information they needed using only Web resources than using the other two resource 


\begin{tabular}{|c|c|c|c|}
\hline \multicolumn{4}{|c|}{$\begin{array}{c}\text { TABLE } 5 \\
\text { Comparison of Means: Web Resources }\end{array}$} \\
\hline ins & $\begin{array}{l}\text { Mean } \\
\text { (Pre- } \\
\text { struction) } \\
\text { strongly }\end{array}$ & $\begin{array}{c}\text { Mean } \\
\text { (Post- } \\
\text { instruction) } \\
\text { lisagree-5 =s }\end{array}$ & $\begin{array}{l}\text { Significance of } \\
\text { Difference } \\
\text { in Means } \\
\text { strongly agree) }\end{array}$ \\
\hline Convenience of using the Web & 4.68 & 4.63 & n.s. \\
\hline Reliability of information found on the Web & 3.86 & 3.99 & n.s. \\
\hline Ease of use (The Web is easy to use.) & 4.24 & 4.46 & $*$ \\
\hline Can find necessary information using the Web only & 3.32 & 2.91 & $* *$ \\
\hline Information can be found quickly on the Web & 4.17 & 3.82 & $* *$ \\
\hline Information on the Web is current & 4.13 & 4.11 & n.s. \\
\hline $\begin{array}{l}\text { Information for the past five years can be found } \\
\text { on the Web }\end{array}$ & 3.50 & 3.51 & n.s. \\
\hline Using the Web is frustrating & 1.93 & 2.19 & $*$ \\
\hline${ }^{a}$ n.s. (not significant) & $p<.001$ & & \\
\hline
\end{tabular}

types. In fact, they perceived no difference in the comprehensiveness of print resources and library databases. These findings lend support to Atkinson and Figueroa's assertion that business students favor electronic resources. The findings also suggest that, without intervention, students would probably use the Web extensively-perhaps exclusivelyfor their research needs.

Next, the data were examined for each individual resource type to determine whether library instruction had any impact on student attitudes. Tables 5, 6, and 7 list the results of this analysis. Column 1 of each table contains the variables of interest; column 2 contains the mean student attitude before instruction; column 3 contains the mean student attitude at the end of the study; and column 4 shows the level of significance of the difference in means. Each table is reviewed below in more depth.

Post-Instruction Attitudes toward Web Resources: In general, Web resources were perceived to be extremely convenient and easy to use both before and after instruction (table 5). Although instruction did not have any impact on the perceived convenience of the Web, students found that the Web was even easier to use after instruction, suggesting that students-even those familiar with the Web-can still benefit from directed instruction in using appropriate Web resources. Nonetheless, students felt that they were less able to locate information quickly using the Web than they were at the beginning of the study, a finding that may be rooted in both the requirements of the research project and the instruction that students received. Specifically, students were asked to include detailed economic-, industry-, and company-related statistics and financial ratios to support their analysis. Although much (though not all) of this information can be found freely on the Web, the fragmented nature of the Internet can make it difficult to isolate. Similarly, the format of a particular data source on the Web, such as the Statistical Abstract of the United States, can make it more difficult to find a particular piece of information than if the student used the same resource in a print format. That students felt they were less able to locate information quickly using the Web may indicate their realization that the Web is indeed fragmented and requires more effort to search effectively.

Equally important, students' perception of the comprehensiveness of the Web also was affected during the course of the study. After instruction, students believed they could not find all of the information 
TABLE 6

Comparison of Means: Library Databases

\begin{tabular}{|c|c|c|c|}
\hline Variables & $\begin{array}{c}\text { Mean } \\
\text { (Pre- } \\
\text { instruction) } \\
(1=\text { strongly }\end{array}$ & $\begin{array}{c}\text { Mean } \\
\text { (Post- } \\
\text { instruction) } \\
\text { disagree-5 }=\end{array}$ & $\begin{array}{l}\text { Significance of } \\
\text { Difference } \\
\text { in Means } \\
\text { strongly agree) }\end{array}$ \\
\hline Convenience of using library databases & 3.32 & 3.46 & n.s. \\
\hline $\begin{array}{l}\text { Reliability of information found on library } \\
\text { databases }\end{array}$ & 3.92 & 4.01 & n.s. \\
\hline Ease of use (Library databases are easy to use.) & 3.32 & 3.37 & n.s. \\
\hline $\begin{array}{l}\text { Can find necessary information using library } \\
\text { databases only }\end{array}$ & 2.80 & 2.78 & n.s. \\
\hline $\begin{array}{l}\text { Information can be found quickly on library } \\
\text { databases }\end{array}$ & 3.12 & 3.11 & n.s. \\
\hline Information on library databases is current & 3.46 & 3.38 & n.s. \\
\hline $\begin{array}{l}\text { Information for the past five years can be } \\
\text { found on library databases }\end{array}$ & 3.64 & 3.73 & n.s. \\
\hline Using library databases is frustrating & 2.92 & 2.79 & n.s. \\
\hline${ }^{\mathrm{a}}$ n.s. (not significant) $\quad * p<.05 . \quad * * p<.01$. & $* * * p<.001$ & & \\
\hline
\end{tabular}

they needed to complete their research using only Web resources. And although the Web was still viewed as easy to use, the study results suggest that students did experience increased frustration using the Web after instruction. Given these findings, it may be that those students who tried to use the Web exclusively for their information needs experienced more frustration than those who chose to move on to other resource types. Or, perhaps students simply began to think critically about the information they found on the Web.

Post-Instruction Attitudes toward Library Databases: Instruction appeared to

\begin{tabular}{|c|c|c|c|}
\hline \multicolumn{4}{|c|}{$\begin{array}{c}\text { TABLE } 7 \\
\text { Comparison of Means: Print Resources }\end{array}$} \\
\hline ins & $\begin{array}{l}\text { Mean } \\
\text { (Pre- } \\
\text { struction) } \\
\text { strongly }\end{array}$ & $\begin{array}{c}\text { Mean } \\
\text { (Post- } \\
\text { instruction) } \\
\text { disagree-5 = }\end{array}$ & $\begin{array}{l}\text { Significance of } \\
\text { Difference } \\
\text { in Means } \\
\text { strongly agree) }\end{array}$ \\
\hline Convenience of using print resources & 2.69 & 3.07 & $* *$ \\
\hline Reliability of information found in print resources & 3.97 & 4.08 & n.s. \\
\hline Ease of use (Print resources are easy to use.) & 2.92 & 3.28 & $* *$ \\
\hline $\begin{array}{l}\text { Can find necessary information using print } \\
\text { resources only }\end{array}$ & 2.62 & 2.83 & n.s. \\
\hline Information can be found quickly in print resources & 2.34 & 2.86 & $* * *$ \\
\hline Information in print resources is current & 3.21 & 3.12 & n.s. \\
\hline $\begin{array}{l}\text { Information for the past five years can be found } \\
\text { in print resources }\end{array}$ & 3.79 & 4.01 & * \\
\hline Using print resources is frustrating & 3.40 & 3.00 & $* *$ \\
\hline an.s. (not significant) & $p<.001$ & & \\
\hline
\end{tabular}




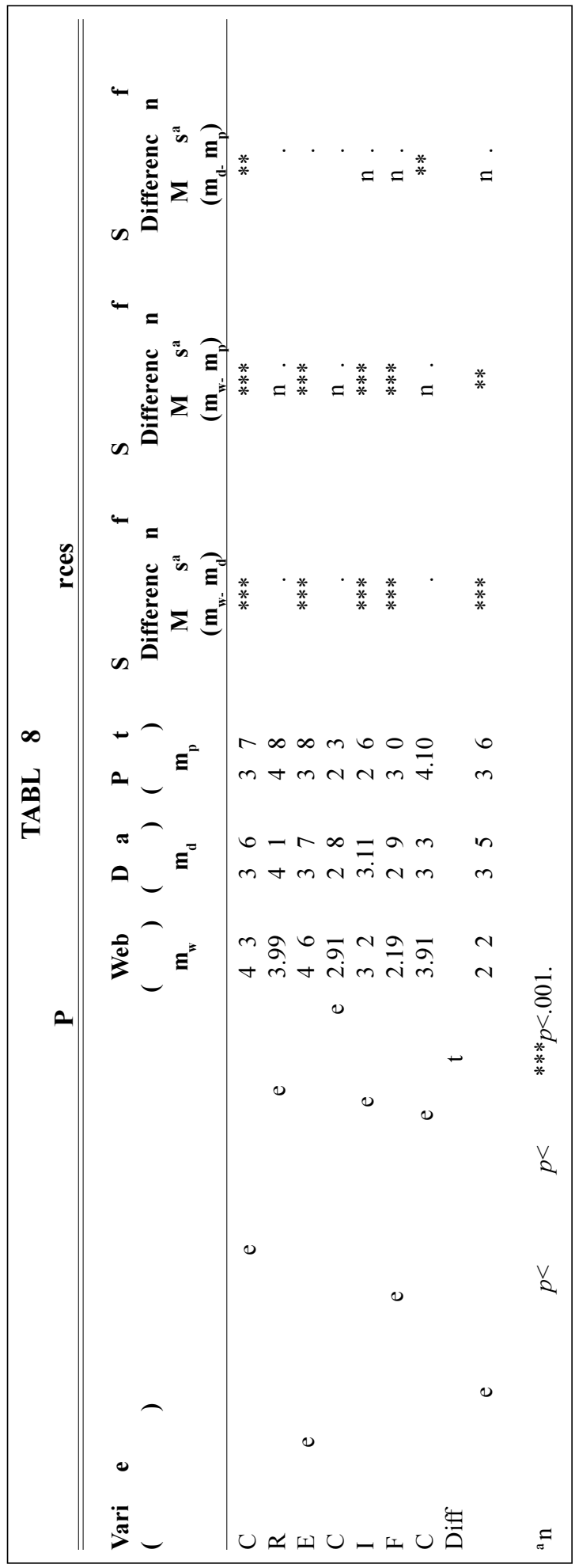

have little impact on students' attitudes toward library databases (table 6). Although there was some decrease in frustration using library databases and an increased perception that these resources were convenient and reliable, these changes were not statistically significant. In general, students perceived these resources as vastly different from the Web. The convenience of full-text access to information through business databases such as $A B I /$ Inform suggests that students should respond enthusiastically to these resources. Yet, students simply seemed to disregard library databases in favor of the Web. It may be that students find library databases to be superfluous; in other words, they may still believe (even after instruction) that all of the information found in these databases also can be found on the Web. Perhaps, too, students find it more difficult to search a library database that requires users to adhere to specific searching rules, as opposed to the free-form searching that can be performed on most search engines. In either case, students' attitudes toward library databases in comparison to the Web merits further exploration, perhaps through more qualitative research methods, to discern subtle differences in perceptions.

Postinstruction Attitudes toward Print Resources: Library instruction appears to have had the most pronounced impact on students' attitudes toward library print resources (table 7). The study findings indicate that at the end of the 
study, students perceived print resources to be significantly more convenient and easier to use than before instruction. Students also thought they were able to find information more quickly using print resources than they could before instruction. Moreover, students seemed more convinced that they could find historical information using print resources. Perhaps most important, a significant decrease was noted in the frustration that students felt using print resources, perhaps because of the design of the library instruction session, which provided students with the chance to apply their newfound knowledge by completing an in-class exercise. In addition, the handout that students received allowed them to focus on learning about the information contained in various print reference materials, as opposed to where the resources were located, thereby reducing the cognitive load required to use these print resources. (Anecdotally, throughout the semester students were often seen in the library carrying these handouts with them as they conducted their research.) These results suggest that effective library instruction can positively influence business students' attitudes about research tools and, more specifically, can impact students' attitudes about print resources.

Comparison of Student Attitudes across Resources after Instruction: Finally, students' attitudes about the three informa- tion formats were compared to determine changes in the attitudinal variables as a result of instruction (table 8).

In general, students continued to show more favorable attitudes toward Web resources, although library instruction minimized many of the differences that students perceived between print resources and library databases. For example, there was little difference in students' frustration using either print resources or library databases, even though they reported significantly less frustration using Web resources. And although students found Web resources to be easier to use, more convenient, and faster than either of the other two resource types, they no longer saw a difference in the ease of use or quickness of library databases and print resources. That students still found library databases more convenient to use than print materials, even after instruction, seems natural, given their ability to access databases remotely.

Most important, by the end of the study students seemed less inclined to think they could find all of the information they needed using only one type of resource, in sharp contrast to their initial assertion that they could rely exclusively on Web resources for all of their information needs. This finding suggests that, over the course of the study, students may have gained a greater understanding of the content and scope of the Web.

\begin{tabular}{|c|c|c|c|}
\hline \multicolumn{4}{|c|}{$\begin{array}{c}\text { TABLE } 9 \\
\text { Comparison of Means for Actual Use of Resources }\end{array}$} \\
\hline$(1=$ compl & $\begin{array}{l}\text { Mean } \\
\text { (Pre- } \\
\text { estruction) } \\
\text { ely accurat }\end{array}$ & $\begin{array}{c}\text { Mean } \\
\text { (Post- } \\
\text { instruction) } \\
\text { e-4 = complet }\end{array}$ & $\begin{array}{l}\text { Significance of } \\
\text { Difference } \\
\text { in Means } \\
\text { etely inaccurate) }\end{array}$ \\
\hline Expect to rely/relied heavily on Web resources & 3.53 & 4.42 & $* * *$ \\
\hline Expect to rely/relied heavily on library databases & 2.46 & 3.21 & $* *$ \\
\hline $\begin{array}{l}\text { Expect to rely/relied heavily on library print } \\
\text { resources }\end{array}$ & 2.02 & 2.76 & $* * *$ \\
\hline a $* p<.05 . \quad * * p<.01 . \quad * * * p<.001$. & & & \\
\hline
\end{tabular}


TABLE 10

Postinstruction Library Use and Research Preferences

\begin{tabular}{lcc} 
Type of Resource Used First to Complete Project & Frequency & Percen \\
\hline Web resources & 63 & 70.0 \\
Library databases & 16 & 17.8 \\
Library print resources & 10 & 11.1
\end{tabular}

Type of Resource Used Most Often to Complete Project

\begin{tabular}{lll}
\hline Web resources & 58 & 64.4 \\
Library print resources & 17 & 18.9 \\
Library databases & 14 & 15.6
\end{tabular}

Number of Visits to the Library during the Semester

\begin{tabular}{lrr}
\hline Student never goes to the library & 2 & 2.2 \\
$1-4$ times per semester & 32 & 35.6 \\
$1-4$ times per month & 30 & 33.3 \\
$1-4$ times per week & 25 & 27.8 \\
About once a day & 1 & 1.1
\end{tabular}

\section{Location Used Most Often to Do Research for Project}

\begin{tabular}{lrr}
\hline Computer at home & 41 & 45.6 \\
University library & 30 & 33.3 \\
Other computer labs at the university & 9 & 10.0 \\
Computer at work & 4 & 4.4 \\
Another university's library & 1 & 1.1
\end{tabular}

\section{Preferred Resource at Preferred Location}

\begin{tabular}{lll}
\hline Web resources & 62 & 68.9 \\
Library print resources & 15 & 16.7 \\
Library databases & 10 & 11.1
\end{tabular}

\section{Findings on Use}

At the beginning of the study, students were asked to predict how heavily they expected to rely on a particular resource type to complete the research project; at the end of the study, they were asked to report the extent to which they actually used each resource type in their research. For example, students were asked to assess the accuracy of statements such as the following: "I expect to rely heavily on Web resources to do the research needed to complete the final project in MGT 435" and "I relied heavily on Web resources to do the research needed to complete the final project in MGT 435" (1 = completely inaccurate; 4 = completely accurate). T-tests then were performed to detect any differ- ences between the students' expectations of use and actual use (table 9). In general, students used more of each type of resource to complete the final project than they had expected, although they still relied most heavily on Web resources, followed by library databases and print resources. When asked if they used more of one specific type of resource as a result of the library instruction, 80 percent of students reported using new print resources, 74 percent used new Web resources, and 65 percent used new library databases.

Perhaps the most dramatic difference is seen when the data on "preferred resource at preferred location" in table 2 are compared with the frequencies listed in table 10. At the beginning of the study, only one 
student reported print resources as a preferred resource. By the end of the study, fifteen students cited print resources as their preferred resource at their preferred research location. Further, the number of students who reported using the university's library most often to do research almost doubled, suggesting that as students increase their level of comfort with library print resources, they will be more inclined to come to the library to complete their research. In sum, students not only used print resources to complete their projects, but some also developed a preference for them.

\section{Conclusion}

This study indicates that changes did indeed occur in the business students' attitudes about, and research behaviors toward, information resources. Their perceptions of the Web as a convenient, easy-to-use, comprehensive research tool were not so ingrained and inflexible as to blind them to the benefits of using other resource types to complete their research projects. This study represents another important step in understanding why students choose the research tools they do to complete assignments. More research must be generated, however, that compares students' perceptions and use of different information resource types. In particular, differences in students' attitudes about library full-text databases and the Web is an area requiring further exploration.

The researchers believe that the changes in student attitudes and behaviors resulted from a number of factors over the course of the semester, including the structure and content of the instruction session and the nature of the students' assignment. During the instruction session, the researchers focused not only on the purpose and use of a variety of information sources but also acknowledged students' perceptions of those resources. In addition, the formal demonstration was reinforced both by inclass exercises and through the students' own research experiences as they completed their final projects. Perhaps most important, a strong collaborative effort between the librarian and the management professor ensured that the instruction session was geared directly toward the students' research project. In fact, the researchers worked closely to design the instruction to reflect the requirements of the research project. This close collaboration was based not only on a shared desire to have the business students explore the full range of information resources available to them, but also on an understanding of the increasing importance of interdisciplinary work between library and business faculty.

Many students who participated in the study also echoed the importance of this collaboration. At the end of the instruction session, a number of students indicated that they wished this instruction had occurred earlier in the business curriculum. Although business faculty agree that information literacy is an important goal for their students, many assume that students are already well versed in business research tools and methods. Others feel that there is not enough room in the business curriculum to address these issues. However, if we are to develop business leaders who are critical and independent thinkers, it is crucial that academic faculty and librarians work together to introduce today's business students to the structure and content of their information environment throughout their academic program so that they will be well prepared to gather the data they need to make effective business decisions upon graduation. It is hoped that this study will provide the needed impetus to expand information literacy efforts in the business school.

\section{Notes}

1. Barbara Valentine, "Undergraduate Research Behavior: Using Focus Groups to Generate Theory," Journal of Academic Librarianship 19 (Nov. 1993): 302.

2. Ibid., 300-304. 
3. Peggy Seiden, Kris Szymborski, and Barbara Norelli, "Undergraduate Students in the Digital Library: Information-seeking Behavior in an Heterogeneous Environment." Available online from http://www.ala.org/acrl/paperhtm/c26.html.

4. Debbie Malone and Carol Videon, "Assessing Undergraduate Use of Electronic Resources: A Quantitative Analysis of Works Cited," Research Strategies 15 (1997): 156.

5. Bryn Geffert and Beth Christensen, "Things They Carry: Attitudes toward, Opinions about, and Knowledge of Libraries and Research among Incoming College Students," Reference $\mathcal{E}$ User Services Quarterly 37 (spring 1998): 281.

6. Brad MacDonald and Robert Dunkelberger, "Full-Text Database Dependency: An Emerging Trend among Undergraduate Library Users?" Research Strategies 16 (1998): 304-5.

7. Bradley P. Tolppanen, "A Survey of World Wide Web Use by Freshman English Students: Results and Implications for Bibliographic Instruction," Internet Reference Services Quarterly 4 (1999): 47.

8. Wen-Hua Ren, "Library Instruction and College Student Self-efficacy in Electronic Information Searching," Journal of Academic Librarianship 26 (Sept. 2000): 326.

9. Philip M. Davis and Suzanne A. Cohen, "The Effect of the Web on Undergraduate Citation Behavior 1996-1999," Journal of the American Society for Information Science and Technology 52 (2001): 309-14.

10. Philip M. Davis, "The Effect of the Web on Undergraduate Citation Behavior: A 2000 Update," College \& Research Libraries 63 (Jan. 2002): 53-60.

11. Susan Davis Herring, "Faculty Acceptance of the World Wide Web for Student Research," College \& Research Libraries 62 (May 2001): 251-58.

12. Deborah J. Grimes and Carl H. Boening, "Worries with the Web: A Look at Student Use of Web Resources," College \& Research Libraries 62 (Jan. 2001): 11-23.

13. Tolppanen, "A Survey of World Wide Web Use by Freshman English Students," 47.

14. Seiden, Szymborski, and Norelli, "Undergraduate Students in the Digital Library."

15. Joann E. D'Esposito and Rachel M. Gardner, "University Students' Perceptions of the Internet: An Exploratory Study," Journal of Academic Librarianship 25 (Nov. 1999): 460.

16. Ibid., 459; see also Nancy J. Young and Marilyn Von Seggern, "General Information Seeking in Changing Times: A Focus Group Study," Reference \& User Services Quarterly 41 (winter 2001): 159-69.

17. Grimes and Boening, "Worries with the Web," 11-23.

18. Davis and Cohen, "The Effect of the Web on Undergraduate Citation Behavior 1996-1999," 309-14.

19. Leo Clougherty et al., “The University of Iowa Libraries' Undergraduate User Needs Assessment," College $\mathcal{E}$ Research Libraries 59 (Nov. 1998): 580-81.

20. Sandra Jenkins, "Undergraduate Perceptions of the Reference Collection and the Reference Librarian in an Academic Library," Reference Librarian 73 (2001): 229-41.

21. Shawn V. Lombardo and Kristine S. Condic, "Convenience or Content: A Study of Undergraduate Periodical Use," Reference Services Review 29 (2001): 334.

22. Tim Bucknall and Rikki Mangrum, "U-Search: A User Study of the CD-ROM Service at the University of North Carolina at Chapel Hill," RQ 31 (summer 1992): 542-53.

23. For examples of studies that measure changes in student knowledge after bibliographic instruction, see Godfrey Franklin and Ronald C. Toifel, “The Effects of BI on Library Knowledge and Skills among Education Students," Research Strategies 12 (fall 1994): 224-37; and Mollie D. Lawson, "Assessment of a College Freshman Course in Information Resources," Library Review 48 (1999): 73-78.

24. Bryn Geffert and Robert Bruce, "Whither BI? Assessing Perceptions of Research Skills over an Undergraduate Career," RQ 36 (spring 1997): 409-17.

25. Ren, "Library Instruction and College Student Self-efficacy in Electronic Information Searching," 323-28.

26. See Anthony Stamatoplos and Robert Mackoy, "Effects of Library Instruction on University Students' Satisfaction with the Library: A Longitudinal Study," College \& Research Libraries 59 (Jul. 1998): 323-34; and Timothy K. Daugherty and Elizabeth M. Carter, "Assessment of Outcome Focused Library Instruction in Psychology." Journal of Instructional Psychology 24 (Mar. 1997): 2933.

27. See Suzanne E. Holler, Phyllis L. Ruscella, and Meg K. Scharf, "We Mean Business: A BI Session for Business Case Analysis Students," Research Strategies 9 (spring 1991): 95-100; Karen Hovde, "Check the Citation: Library Instruction and Student Paper Bibliographies," Research Strategies 17 (2000): 3-9; and Maurita Peterson Holland and Christina Kelleher Powell, "A Longitudinal Survey of the Information-seeking and Use Habits of Some Engineers," College \& Research Libraries 56 (Jan. 1995): 7-15.

28. Joseph D. Atkinson III and Miguel Figueroa, "Information-seeking Behavior of Business 
Students: A Research Study," Reference Librarian 58 (1997): 59-73.

29. Ibid., 66.

30. Thomas R. Mirkovich, "Investment Information in Academic Libraries: Undergraduate and MBA Students," RQ 35 (spring 1996): 382-87.

31. Atkinson and Figueroa, "Information-seeking Behavior of Business Students," 69.

32. Ibid., 72.

33. The authors pretested the questionnaire during the spring and summer semesters of 2001 and revised it based on the feedback they received and the results of pilot statistical tests, as appropriate.

34. Atkinson and Figueroa, "Information-seeking Behavior of Business Students." 